\title{
Body Donation, Teaching, and Research in Dissection Rooms in Spain in Times of Covid-19
}

\author{
Maria-Cristina Manzanares-Céspedes, (D) ${ }^{1}$ Miki Dalmau-Pastor, (D) ${ }^{1,2 \star}$ Clara Simon de Blas, (D) ${ }^{3}$ \\ María Teresa Vázquez-Osorio (iD) 4 \\ ${ }^{1}$ Human Anatomy and Embryology Unit, Department of Pathology and Experimental Therapeutics, Faculty of \\ Medicine and Health Sciences, University of Barcelona, Barcelona, Spain \\ ${ }^{2}$ Minimally Invasive Foot and Ankle Society (MIFAS), Group of Research and Study in Minimally Invasive Surgery of \\ the Foot (GRECMIP), Merignac, France \\ ${ }^{3}$ Department of Statistics and Operations Research, Computer Science School, Rey Juan Carlos University, \\ Madrid, Spain \\ ${ }^{4}$ Bodies Donation and Dissection Room Center, Department of Anatomy and Embryology, Faculty of \\ Medicine, Complutense University of Madrid, Madrid, Spain
}

\begin{abstract}
The state of alarm due to Covid-19 pandemic in Spain stopped all educational and most university research activities. The Spanish Anatomical Society (SAE) Consensus Expert Group on Body Donations piloted a study based on a questionnaire to know the status of body donations and dissection activities during the lockdown, as well as the future implications of Covid-19 pandemic for body donation programs and anatomy teaching. The questionnaire results show that Spanish Universities refused body donations and stopped all dissection research and teaching. The Covid-19 expected influence on anatomy teaching was referred to the increase in teaching workforce and resources required to apply the new safety measures to future practical activities, as well as to prepare and adapt teaching material for online-only programs. The application of reinforced safety measures was expected to be perceived by the respondent's students as a gain in teaching quality, while the transformation of the anatomy courses in online-only programs will be perceived as a quality decrease. The respondent's concerns about future institutional implications of the pandemic were related to increased costs of the adaptation of the facilities and the reinforced preventive measures, as well as the eventual decrease in donations. The complete lockdown applied to dissection rooms was not justified by scientific evidence and represented a break of the confidence deposed in the institutions by the donors. A consensus is required for the adoption of a renewed, comprehensive protocol for present and future body donations including the evidence Covid-19 pandemic has contributed to create. Anat Sci Educ 14: 562-571. () 2021 The Authors. Anatomical Sciences Education published by Wiley Periodicals LLC on behalf of American Association for Anatomy.
\end{abstract}

Key words: gross anatomy education; medical education; undergraduate education; Covid-19; dissection; translational research

\begin{abstract}
${ }^{*}$ Correspondence to: Dr. Miki Dalmau-Pastor, Human Anatomy and Embryology Unit, Department of Experimental Pathology and Therapeutics, Faculty of Medicine and Health Sciences, Health University of Barcelona Bellvitge Campus (HUBc), c/Feixa Llarga SN, 08907, Hospitalet, Barcelona, Spain. E-mail: mikeldalmau@ub.edu

Additional supporting information can be viewed in the online version of this article.

Received 22 June 2020; Revised 9 April 2021; Accepted 18 April 2021.

Published online 27 August 2021 in Wiley Online Library (wileyonlinelibrary.com). DOI 10.1002/ase.2093

(C) 2021 The Authors. Anatomical Sciences Education published by Wiley Periodicals LLC on behalf of American Association for Anatomy

This is an open access article under the terms of the Creative Commons Attribution-NonCommercial-NoDerivs License, which permits use and distribution in any medium, provided the original work is properly cited, the use is non-commercial and no modifications or adaptations are made.
\end{abstract}

\section{INTRODUCTION}

The pandemic situation caused by the novel Coronavirus originated in the Chinese city of Wuhan in December 2019 has changed everyday life as well as academic life around the world (Burgess and Sievertsen, 2020; George et al., 2020; Li et al., 2020). This virus was termed Covid-19 and caused the World Health Organization to declare a public health emergency on 30 January 2020 (Mahase, 2020). The spread of the disease in Europe was very swift, and the state of alarm was decreed in Spain on 14 March 2020. With immediate effect educational and university research activities were stopped in the national territory. The lockdown of the population, the elevated mortality of Covid-19, and the restrictions applied to burial and cremation procedures made the management of ordinary body 
donations very complicated. In addition, since all Spanish universities (50 public, 26 private) decreed a complete closure of services and facilities, the administrative procedures for the management of the body donation programs were suspended. Similar situations have been reported at a global level as a consequence of the pandemics (Evans et al., 2020; Gupta and Pandey, 2020; Longhurst et al., 2020; Ooi and Ooi, 2020; Pather et al., 2020; Ravi, 2020; Singal et al., 2020; Bond and Franchi, 2021; Onigbinde et al., 2021).

The immediate and dramatic impact of the Covid-19 pandemic in the health sciences education at all levels has been a matter of deep concern for both academia and students faced with the closure of the practical anatomy laboratories and clinics during the full lockdown period. The sudden transformation of face-to-face (F2F) teaching to a completely online approach required a great deal of flexibility and effort from both health sciences teachers (Iyer et al., 2020; Longhurst et al., 2020; Moskowitz et al., 2020; Pather et al., 2020; Quinn et al., 2020; Iwanaga et al., 2021; Saverino et al., 2021) and students (Franchi, 2020; Srinivasan, 2020). In Spain, dissection rooms are used by a variety of students including medicine, nursery, dentistry, physiotherapy, podiatry, and by post-graduate students attending surgical training courses.

In Spain, dissection rooms and body donation programs (BDP) are managed by universities, under the administrative tutelage of the autonomous governments, as is the case for public health services. Cadaver and organ donation options are included in the living will documents elaborated by most autonomous governments (BOE, 2002). Since 1992, Spain has maintained the world record for organ donations, attaining 48.0 PMP (per million population) donors in 2019, as compared with the PMP values reported by the United States (32.8), Australia (22.3), and the European Union from Greece, 4.1 to Portugal, 33.4 (ONT, 2020). The living will includes the possibility of donating the body if organ donation for transplantation is not feasible. This simplified administrative procedure constitutes the main reason for the increase in body donations experienced by all Spanish BDPs in the last decade. However, there is a lack of a common legislation at a national level to regulate the use of donation cadavers for academic activities, and the sole national law to regulate the management of dead bodies dates from 1974 (BOE, 1974). Consequently, there is not a national register of donations.

In order to address the legal aspects, as well as the necessity of a common regulatory structure for the BDP, the Spanish Anatomical Society (SAE) constituted in 2018 an expert group to elaborate consensus documents about the management, the administration, and the ethical implications of cadaver donation. This group reported to the General Assembly of the SAE during virtually held meeting on 11 May 2020 on the situation caused by the Covid-19 state of alarm and on the lockdown status of dissection rooms, that remained closed in all Spanish higher education institutions with only one exception of the Complutense University of Madrid. Director of the Complutense University body donation center informed the SAE that they had requested the advice of the university legal services. The answer they received was that "the commitment acquired with the donor, once he/she has expressed his/her will to donate the body after his/her death, constitutes a contract between two parties, in which the University and the BDP are forced to fulfill under any circumstance." As a consequence, the BDP was decreed as a "critical" service by the Rector of the Complutense University. All public and private services decreed as critical were legally allowed to remain open to operate during the different lockdown phases, thus the Complutense University BDP is the only one higher education institution in Spain receiving donations to date.

However, despite existing clear indications from the Spanish Government as how the bodies of the Covid-19 victims should be handled (SEAP-IAP, 2020), and the existence of numerous national laws (CDC, 2020; Government of India, 2020; UK Law, 2020), international regulations (ECDC, 2020; Finegan et al., 2020; Kramer et al., 2020; WHO, 2020), and guidelines and technical reports (FICEM, 2012; Sañudo, 2015; RCP, 2020; Vázquez-Osorio, 2020) about the best practices in the handling, management, and preventive measures to apply to cadavers, most of the universities in Spain decided to suspend all BDP activities.

The situation was discussed by the SAE General Assembly that resolved that a survey will be proposed to all attending BDP Directors. A questionnaire was prepared in order to assess the situation of the teaching and research activities in the dissection facilities, as well as the expert group members and BDP director's perceptions about the influence of the Covid-19 pandemics and the consequent increase in preventive measures will have in the future academic activities to be carried out in the dissection rooms. The present article reports the results of this questionnaire regarding the status of the dissection activities in the respondent's institutions. This analysis is aimed to facilitate the discussion of the proposed changes to the donation protocols and procedures that will be included in the SAE consensus documents about the management, the administration, and the ethical implications of cadaver donation.

\section{MATERIALS AND METHODS}

The aim of this survey was to get a clear picture of the initial measures taken by the BDPs about the donations as well as the activities of the dissection rooms in response to the Covid-19 crisis. The purpose of this survey was to provide information to the SAE expert group to discuss the eventual need to propose changes to the cadaver donation process in the Spanish Universities, and to determine the scientific evidence supporting decisions taken as a consequence of the Covid-19 pandemics.

An electronic ad hoc 15-item questionnaire was designed and piloted by the SAE, in order to know the situation in the dissection rooms with respect to teaching and research activities during the initial lockdown of the academic institutions, and the perceptions of the participants about the next academic year.

The questionnaire was designed in Spanish language and used single-answer or multiple-choice questions to assess the current institutional decisions taken about the management of the dissection rooms and the BDP, the future implications of the Covid-19 pandemics on the BDPs and on the teaching of anatomy as well as on the perception of the SAE members about the eventual loss of confidence of the students on the quality of the anatomical education as a consequence of the Covid-19 situation. An English translation of the questionnaire is available as the Supplemental Material File Appendix 1 to this manuscript.

Once reviewed, the questionnaire was approved by the Bioethics Committee (Institutional Review Board) of the University of Barcelona. The questionnaire was then distributed to the SAE expert group on body donations and dissection room management. The survey was sent to 15 directors of the body donor services in Spain on 25 May 2020 and data were collected until 1 June 2020.

The purpose of this survey was also to create a map of responding BDPs to build a community of Spanish institutions dedicated to education and research in human anatomy. 
Nine responses from a total target of 15 body donor services in Spain were received. The respondents were from different geographical regions in Spain, were diverse in terms of sex (six males, three females) and seniority (seven seniors, two juniors). The seniority was assessed using the same criteria-more than ten publications in a period of more than ten years reported by Bennett et al. (2020).

Although the questionnaire was designed using singleanswer or multiple-choice questions, the same criteria were used to categorize all responses in order to compute Kendall's Tau B correlations and Cronbach's alpha (Cronbach, 1951) to assess the validity and the reliability (respectively) of the instrument. All test and data analysis were conducted using SPSS statistical package, version 18 for Windows (IBM Corp., Armonk, NY). Finite Population Correction Factor (FPC) was used to compute the confidence intervals for the percentage of responses in the sample, given in equation below Eq. (1).

$$
F P C=\sqrt{\frac{N-n}{N-1}}
$$

where $N$ is the population size and $n$ is the sample size.

Kendall's Tau B correlation, a nonparametric measure of the strength and direction of association between two variables was used to assess the significance of the relation between the rankings. Cronbach's alpha was applied to measure the internal consistency between the items of the questionnaire. A reliability coefficient of $0.6-0.70$ or higher was considered "acceptable," and 0.8 or greater a "very good level" as in most social science research (Hulin et al., 2001).

\section{RESULTS}

The survey was applied to a sample of 15 directors of dissection rooms and/or body donation programs and were collected from 25 May to 1 June 2020. During that period nine directors of BDP pertaining to the Spanish Anatomical Society responded, which supposes the $60 \%$ of the total population susceptible to respond to the questionnaire (15 donation centers). Therefore, an error sample $\varepsilon=2.83 \%$ was derived considering a significance level $\alpha=0.05$ following equation Eq. (2).

$$
\varepsilon^{2}=\frac{\frac{N * Z_{\alpha}^{2} * P *(1-P)}{n}-Z_{\alpha}^{2} * P *(1-P)}{N-1}
$$

where $n$ is the sample size, $N$ is the total population size, $P$ value is the proportion (in case is unknown, $P=0.5$ ), $Z_{\alpha}^{2}$ is the right tail value for a normal distribution with mean cero and variance 1 considering a significance level $\alpha$ (in this case, $Z_{\alpha}^{2}=1.96$ ) and $\varepsilon$ is the error sample. A corrector for finite populations was applied.

As pointed out by Sijtsma (2009), many psychologists led to the interpretation of alpha as a measure of the internal consistency of a test. The value obtained by the associated Cronbach alpha was 0.702 .

The reported data cover four main areas, the first being the current situation and management of eventual Covid-19 cadaver donations. Then, the prevision of the respondents about the future implications of the pandemics in the BDP organization as well as in the teaching of anatomy. Finally, the eventual change in the student's perception on the quality of their anatomic formation due to the pandemic measures, including the eventuality of an online-only academic year.

\section{Current Situation and Management of the Eventual Covid-19 Cadaver Donations}

The directors of dissection rooms and body donation programs reported that both the dissection activities and the donation programs in the universities were severely limited (Table 1). Majority of respondents $(66.7 \%)$ reported to be closed both for teaching and for research activities, as well as to receive potential donors and cadaver donations, in application of the complete lockdown active in that period. The exceptions to that general rule were three directors: one reported the possibility of carry out research activities, but no teaching or donations $(11.1 \%)$; a second one, the possibility of carry out teaching activities, but no research or donations $(11.1 \%)$; and the third, the possibility to receive cadaver donations, but not to carry out teaching or research activities $(11.1 \%)$. Interestingly, this last institution was the only one to decree the body donation service as a "critical" one, based on the position of the institutional legal advisors that the donation remains a legally binding contract between the donor and the Institution.

In a previous meeting of the SAE expert group the main guidelines on the management of cadavers were reviewed, and a consensus was reached as per the redaction of a document reporting a standardized protocol to be adopted by the SAE. Thus, two questions were included regarding the tests and procedures to apply in future donations (Table 1). About $22.2 \%$ respondents reported that the donations were suspended sine die; while $22.2 \%$ reported that the cadavers would be directly frozen, while waiting for tests. In addition, $33.3 \%$ participants would carry out specific Covid-19 tests, added to the usual protocol (including HIV, Hepatitis and prions) and $11.1 \%$ would continue with the usual tests while another $11.1 \%$ would submit the cadavers to the usual embalming procedure, which was then reported as the method of choice to avoid crossed contamination (Balta et al., 2015). A second question aimed to a potential future donation of a donor suspected of Covid-19: this situation was not possible for the $44.4 \%$ of the institutions not accepting donations during the questionnaire period. Referring to the institutions accepting donations, one director reported that one of their recent donations included symptoms compatible with pneumonia in the patient's clinical history, and another one revealed his concern about a donation received on 1 March (before official lockdown) with "pneumonia" as the reported cause of death. Regarding the possibility of an analytic result confirming the Covid-19 in an already accepted cadaver, $55.6 \%$ (five of nine respondents) of the answers were negative, while in the $44.4 \%$ positive cases, different protocols were to be applied: two services $(22.2 \%)$ decided the embalming, in one case before freezing the body, while another $(11.1 \%)$ decided to directly freeze the cadaver and a fourth one $(11.1 \%)$ opted for declining the donation. Only three cases of accepted body donations with Covid-19 as death cause were reported $(33.3 \%)$; two of the bodies $(22.2 \%)$ were frozen after embalming, and in one case $(11.1 \%)$ the donation was declined.

Significant Kendall's Tau B correlations were found between the possibility of future acceptance of cadaver donations during the pandemic and the current situation (correlation 0.695 significant at 0.05 bilateral level), were the $42 \%$ opted for freeze the cadaver, the $42 \%$ made analytics confirming Covid and in one case no change was adopted with respect to the previous cadaver management procedure. Therefore, there is a high correlation between future possibility of the center to accept cadavers with Covid-19 as death cause and the current actuation protocol of the center. Centers that are open and currently 


\begin{tabular}{|c|c|c|c|}
\hline \multirow{2}{*}{$\begin{array}{l}\text { Current situation of the dissection room: teach- } \\
\text { ing activities }\end{array}$} & Closed & $8(88.9)$ & {$[0.57 ; 0.98]$} \\
\hline & Open & $1(11.1)$ & {$[0.0 ; 0.27]$} \\
\hline \multirow{2}{*}{$\begin{array}{l}\text { Current situation of the dissection room: re- } \\
\text { search activities }\end{array}$} & Closed & 7 (77.8) & {$[0.57 ; 0.98]$} \\
\hline & Open & $2(22.2)$ & {$[0.02 ; 0.43]$} \\
\hline \multirow{4}{*}{$\begin{array}{l}\text { Protocol to be applied in case of future body } \\
\text { donation acceptance }\end{array}$} & Body freezing & $2(22.2)$ & {$[0.02 ; 0.43]$} \\
\hline & Covid-19 Tests & $3(33.3)$ & {$[0.10 ; 0.57]$} \\
\hline & Same than before pandemic & $1(11.1)$ & {$[0.0 ; 0.27]$} \\
\hline & Body embalming & $1(11.1)$ & {$[0.0 ; 0.27]$} \\
\hline \multirow{3}{*}{$\begin{array}{l}\text { Protocol applied in case of accepted donations } \\
\text { with potential risk of Covid-19 }\end{array}$} & Body donation declined & $1(11.1)$ & {$[0.0 ; 0.27]$} \\
\hline & $\begin{array}{c}\text { Body freezing after } \\
\text { embalming }\end{array}$ & $1(11.1)$ & {$[0.0 ; 0.27]$} \\
\hline & Body embalming & $1(11.1)$ & {$[0.0 ; 0.27]$} \\
\hline \multirow{2}{*}{$\begin{array}{l}\text { Donations intended to be accepted with } \\
\text { Covid-19 as death cause? }\end{array}$} & Yes & $1(11.1)$ & {$[0.0 ; 0.27]$} \\
\hline & No & 8 (88.9) & {$[0.57 ; 0.98]$} \\
\hline \multirow{2}{*}{$\begin{array}{l}\text { Protocol applied to donations received with } \\
\text { Covid-19 as death cause }\end{array}$} & Non reported cases & $6(66.7)$ & {$[0.43 ; 0.89]$} \\
\hline & Body donation declined & $1(11.1)$ & {$[0.0 ; 0.27]$} \\
\hline
\end{tabular}

Number of respondents $(n=9)$; CI, confidence interval.

accept cadavers with Covid-19 as cause of death, would accept bodies with Covid-19 in the future (freezing them or doing tests to confirm the cause of death), while those that are closed or do not accept donations, will not accept bodies in the next time horizon. This resulted also in significant Kendall's Tau B correlations with the attempt to donate a body with the mention of Covid19 as the "cause of death" in the medical record/death certificate (correlation 0.84 significant at 0.05 bilateral level) where in five cases (83\%) no donations with "Covid-19" as death cause were received and the performance donations with Covid-19 (correlation 0.707 significant at 0.05 bilateral level). The attempt to donate a body with the mention of Covid-19 as a "cause of death" in the medical record/death certificate and the actuation with Covid-19 donations was also significatively correlated (correlation 0.809 significant at 0.05 bilateral level).

\section{Future Implications for Body Donation Programs}

When asked about perception of the pandemic's impact on the body donations, only one of the responders $(11.1 \%)$ considered that it would not have a noticeable impact. About 33.3\% participants expected a decrease in future donations, while $55.6 \%$ were not able to preview the impact of the situation on future donations (Table 2 ).

\section{Increased Costs and Structural Changes of the Installations}

The need for structural changes in the dissection rooms such as the use of mobile separation systems or devices, due to the new safety requirements of social distance, was reported by $44.4 \%$ of the directors (Table 2 ). Another $44.4 \%$ (four of nine respondents) considered that no changes were required in their respective installations, while, on the contrary, one participant $(11.1 \%)$ disclosed the need for a complete refurbishment of the dissection rooms (Table 2). None of the responders reported to have received any indication from their respective academic $(77.7 \%)$ or regional authorities $(22.2 \%)$ about the need for changes in the dissection rooms to adapt it to the new Covid-19 preventive measures when the academic activities eventually resume (Table 2).

Table 2 reflects the director's perceptions about the possible increase in costs due to the added preventive measures. About $55.6 \%$ (five of nine respondents) estimated that costs for the dissections would increase between a 0 and a $20 \% ; 22.2 \%$ estimated an increase between the 21 and a $50 \%$ of the costs, while $11.1 \%$ were unable to estimate the eventual increase and another $11.1 \%$ considered that no cost increase was to be expected. Most directors expected that their Institution would cover totally $(33.3 \%)$ or partially $(55.6 \%)$ these extra costs, with only one $(11.1 \%)$ reporting a probable negative answer. 


\begin{tabular}{|c|c|c|c|}
\hline Question & Response Options & Number of Responses $n(\%)$ & CI $95 \%$ \\
\hline \multirow{2}{*}{$\begin{array}{l}\text { In your opinion, is there a change in body dona- } \\
\text { tions to be expected as a result of the Covid- } 19 \\
\text { pandemic? }\end{array}$} & $\begin{array}{l}\text { I cannot give an } \\
\text { estimation }\end{array}$ & $5(55.6)$ & {$[0.31 ; 0.8]$} \\
\hline & No & $1(11.1)$ & {$[0 ; 0.27]$} \\
\hline \multirow{2}{*}{$\begin{array}{l}\text { Which of the following best describes the } \\
\text { level of structural change that you expect your } \\
\text { institution to undertake in the dissection room } \\
\text { to resume teaching as a result of the Covid- } 19 \\
\text { pandemic? }\end{array}$} & No changes are required & $4(44.4)$ & {$[0.2 ; 0.69]$} \\
\hline & $\begin{array}{l}\text { Complete redesign of } \\
\text { the dissection room is } \\
\text { required }\end{array}$ & $1(11.1)$ & {$[0 ; 0.27]$} \\
\hline \multirow{2}{*}{$\begin{array}{l}\text { After more than } 2 \text { months since the confinement } \\
\text { of the population was decreed, do you have in- } \\
\text { structions from your University/regional authori- } \\
\text { ties on the level of structural change required } \\
\text { in the dissection room to resume teaching as a } \\
\text { result of the Covid-19 pandemic? }\end{array}$} & No (University) & $7(77.8)$ & {$[0.57 ; 0.98]$} \\
\hline & Yes & $0(0.0)$ & \\
\hline \multirow{4}{*}{$\begin{array}{l}\text { In your opinion, will there be an increase in the } \\
\text { costs of the dissection room to reinforce preven- } \\
\text { tion protocols for teachers and students? }\end{array}$} & $\begin{array}{l}\text { A minimum increase }(0 \%- \\
20 \%) \text { expected }\end{array}$ & $5(55.6)$ & {$[0.31 ; 0.8]$} \\
\hline & No expected increase & $1(11.1)$ & {$[0 ; 0.27]$} \\
\hline & $\begin{array}{l}\text { A significant increase } \\
(20 \%-50 \%) \text { expected }\end{array}$ & $2(22.2)$ & {$[0.02 ; 0.43]$} \\
\hline & $\begin{array}{l}\text { I cannot estimate the } \\
\text { eventual increase }\end{array}$ & $1(11.1)$ & {$[0 ; 0.27]$} \\
\hline \multirow{2}{*}{$\begin{array}{l}\text { Do you expect these costs to be covered by your } \\
\text { university? }\end{array}$} & Yes, totally & $3(33.3)$ & {$[0.1 ; 0.57]$} \\
\hline & Yes, partially & $5(55.6)$ & {$[0.31 ; 0.8]$} \\
\hline
\end{tabular}

Number of respondents $(n=9)$; CI, confidence interval.

Significant Kendall's Tau B correlations were found between the need for structural changes in the dissection rooms and the consideration that the Institution would cover these extra costs (correlation -0.653 significant at 0.05 bilateral level), were in one case the director $(11.1 \%)$ consider minimum changes to be totally covered and in two cases $(22.2 \%)$ expected considerable changes to be partially covered by the Institution. However, in four cases $(44.4 \%)$ the directors did not consider the need for structural changes. However, they expected a small increase in the dissection rooms costs due to the added preventive measures, to be covered at least partially by the Institution.

\section{Future Implications of the Pandemics for the Teaching of Anatomy: Teaching Workforce and Resources}

More than half $(55.6 \%)$ of the participants reported to have a sufficient number of teachers to carry on an online-only anatomy practical course by maintaining its quality, while $44.4 \%$ reported a lack of teaching workforce. The same percentages were reported when asked about the material resources available to create, adapt, or preserve teaching materials to maintain the teaching quality for a completely online academic year. In addition, $55.6 \%$ reported not to have the number of professors required to comply with new safety procedures in terms of reducing the number of students per practical group, while $44.4 \%$ reported to have an adequate teaching workforce for these eventual requirements (Table 3 ).

To apply the new safety and prevention protocols and social distance while maintaining the teaching quality of the practical courses, personal protective equipment, as well as material resources (tests, disposable dissection material, etc.) are required (Table 3). Majority $(77.8 \%$ ) of respondents reported not to have those resources available, and only $22.2 \%$ reported to be adequately furbished of protective materials.

Significant Kendall's Tau B correlation was found between the availability of a sufficient number of teachers to carry on an online-only anatomy practical course by maintaining its quality in case of impossibility of retake practices in the dissection rooms. Therefore, there is a positive correlation between the teaching workforce at the center to face remote teaching while maintaining the quality of teaching. In other words, centers with high availability may face semi-F2F or remote teaching, while centers with low availability foresee a drop in the quality of teaching if no F2F was possible. In four cases the director $(44.4 \%)$ reported to have enough teachers to carry out onlineonly teaching whereas in four cases $(44.4 \%)$ they considered that more personnel were needed to comply with new safety procedures in terms of reducing the number to students in the practical groups for on-site activities. 


\section{Implications on the Teaching Quality as Perceived by the Students}

Regarding the participants' opinion on the student's perception of the quality of the anatomy teaching if all activities were organized entirely online, shown in Table 4, 66.7\% (six of nine respondents) reported that this will be perceived as a decrease in the quality of their anatomical teaching. The other 33.3\% considered that the perception of the teaching quality by the students will not change. On the contrary, when asked about the student's perception of the teaching quality of the practical courses once the new preventive measures will be applied to the anatomy practical courses, $55.6 \%$ (five of nine respondents) suggested that this will be perceived as an increase in the quality, while $44.4 \%$ reported that no change in the student's perception was to be expected. No significant Kendall's Tau B correlation was found between both opinions.

\section{DISCUSSION}

A complete cessation of teaching activities at a global level is a new situation, despite some antecedents during previous epidemic outbursts (Patil and Yan, 2003). It has a major negative impact on the learning process of any student, and that it forces the professorate to rapidly explore new teaching options (Ahmed et al., 2020; Eberlová and Mansfeld, 2020; Iwanaga et al., 2021). Most of the authors that, as $77.8 \%$ of the responders, reported the restriction or the total interruption of anatomy laboratory teaching practices during the pandemics shared also their experiences and the methods and instruments used to adjust their teaching approaches (Moszkowicz et al., 2020; Srinivasan, 2020; Saverino et al., 2021). The closure of the dissection rooms and the sudden transformation from a very practically oriented F2F teaching to a completely online environment have elicited a global debate. Some initiatives have been proposed to improve anatomy teaching with the implementation of e-learning methods in a move toward a blended learning approach (Longhurst et al., 2020; Pather et al., 2020).

The concern of students and professors with regard to a diminution of education value, as well as difficulties with online evaluations became evident (Quinn et al., 2020; Rose, 2020). The limitation of all practical F2F activities, and its substitution by online-only activities will cause, in the opinion of $66.7 \%$ of the participants, the student's perception of a decrease in the quality of their Anatomical formation. Indeed, despite the benefits reported by the substitute use of on-line and media teaching materials (Desai, 2020; Zingaretti et al., 2020) the absence of anatomical dissection is seen by the students as a loss of a crucial part of their development to become a Health professional (Desai, 2020; Franchi, 2020; Srinivasan, 2020).

The social restrictions to be applied to resume the University courses were not defined in Spain until September 2020. The autonomic (regional) authorities in charge of the administration of the public Universities had not published a definitive decision about the academic year 2020/2021 when the questionnaire was sent, so the Academia main concern was the eventuality of a first semester or a whole academic year to be developed uniquely online. In the event of an online-only resuming of anatomy teaching, $44.4 \%$ of the participants in the questionnaire considered that their Departments had neither enough resources nor a sufficient teaching workforce to ensure a quality teaching, which was in agreement with the reports of anatomy professors worldwide (Evans et al., 2020; Ravi, 2020).

Regarding the management of bodies with suspected or confirmed dead from Covid-19, clear indications have been published since the pandemic declaration by state administrations

\section{Table 3.}

Increased Workforce and Material Requirements for the Anatomy Teaching in Spain when Teaching in Dissection Rooms will be Resumed

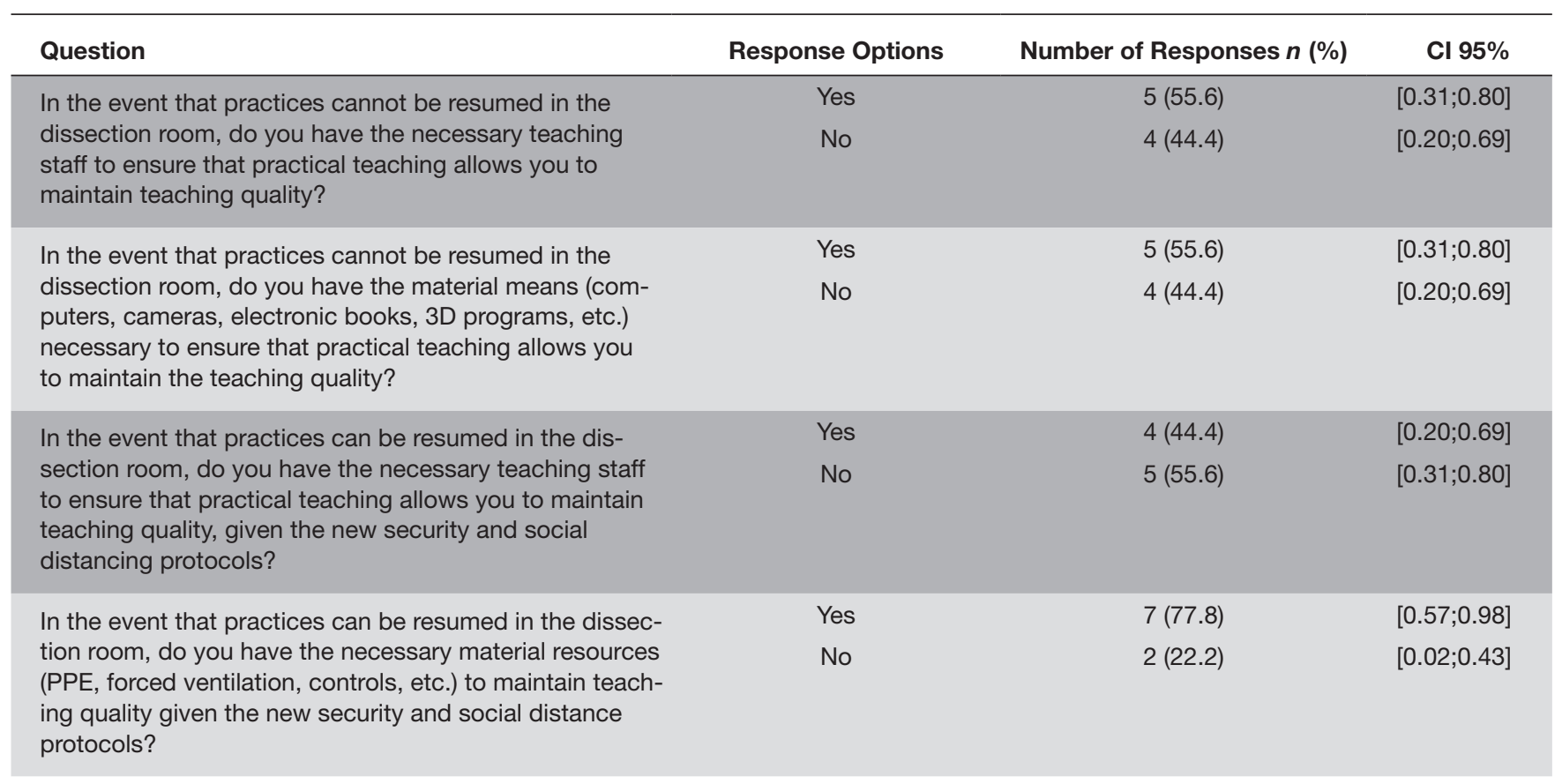

Number of respondents $(n=9)$; CI, confidence interval; PPE, personal protective equipment. 


\section{Table 4.}

Student's Perception about Anatomy Teaching after Covid-19 in Spain

\begin{tabular}{lcc}
\hline Question & Response Options & Number of Responses $\boldsymbol{n}$ (\%) \\
\hline $\begin{array}{l}\text { In your opinion, what will be the perception of } \\
\text { the students about the quality of teaching in the } \\
\text { event that practices cannot be resumed in the } \\
\text { dissection room? }\end{array}$ & $\begin{array}{c}\text { Decrease in the teaching } \\
\text { quality }\end{array}$ & $6(66.7)$ \\
$\begin{array}{l}\text { In your opinion, what will be the perception of the } \\
\text { students about the quality of teaching in the event } \\
\text { that practices can be resumed in the dissection } \\
\text { room with the appropriate prevention measures? }\end{array}$ & $\begin{array}{c}\text { Without changes } \\
\text { Increase in the teaching } \\
\text { quality }\end{array}$ & $4(33.3)$ \\
\hline
\end{tabular}

Number of respondents ( $n=9)$; CI, confidence interval.

(CDC, 2020; DHHA, 2020; SEAP-IAP, 2020) as well as international health authorities (ECDC, 2020; WHO, 2020) and international and national scientific associations and experts (Sañudo, 2015; Kramer et al., 2020; Vázquez-Osorio, 2020; Lemos et al., 2021; Onigbinde et al., 2021). In a recent review of the different guidelines for the management of cadavers during the pandemics, Dijkhuizen et al. (2020) reported that there is no scientific evidence proving that a Covid-19 dead human body is still infectious. However, the majority of respondent's institutional authorities applied a complete closure of both the donation services and the research activities in the dissection room, a decision not based on solid scientific evidence, but on what World Health Organization (WHO) (Zarocostas, 2020) and Pan American Health Organization (PAHO, 2020) defined as "infodemic" (Sentell et al., 2020).

Formalin inactivates the SARS-CoV-2 virus (Aquila et al., 2020; Pambuccian, 2020). A recent revision of the safe management of bodies of the pandemic victims (Yaacoub et al., 2020) also reports that a $70 \%$ concentration of ethanol, the usual hospital disinfectants and even household detergents, followed by a $0.1 \%$ solution of hypochlorite are effective to eliminate the virus (ECDC, 2020). This is also the case for the tried-andtrue cadaver embalming methods cited in most reports (Balta et al., 2015; Ravi, 2020; Vázquez-Osorio, 2020; Lemos et al., 2021; Onigbinde et al., 2021). Consequently, the risk in carrying out academic activities directed by experienced academicians working with samples submitted to the usual disinfection, embalming, and personal safety procedures employed in the respondent's dissection rooms is limited (Vazquez-Osorio, 2020). A strict enforcement of the adequate safety protocols and procedures has recently been proposed by Onigbinde et al. (2021) and Lemos et al. (2021) to be applied to resume dissection room activities, including preventive measures proposed by the SAE members and reported in the questionnaire.

All but one dissection room of the 15 included in the SAE group were closed for research as well as for teaching activities, with a major impact on numerous projects. It is important to notice how all research projects were forced to stop by the academic authorities, regardless of the specific risk that could represent. No difference was made between research projects including airway or lung manipulations, that could be considered as risky (El-Boghdadly et al., 2020; Onigbinde et al., 2021) and dissections of musculoskeletal structures or histological investigations on previously embalmed samples, that are free from SARS-CoV-2 virus (Pambuccian et al., 2020). This fact contrasts with the numerous guidance papers from scientific societies dedicated to the airway management of Covid-19 in living patients (El-Boghdadly et al., 2020). Non-aerosol generating procedures in head and neck surgery (Wu et al., 2020), otolaryngology (Mick and Murphy, 2020), anesthesia (Herman et al., 2021), or orthopedic surgery (Bassso et al., 2020; Hirschmann et al., 2020) have been carried out in hospitals during the Covid-19 outburst. Moreover, a growing number of articles report using cadavers to simulate aerosol-generating surgical procedures in order to assess the risks and propose recommendations for the practitioner's and patient's safety and protection from SARS-CoV-2 virus (Workmann et al., 2020; Khoury et al., 2020; Sharma et al., 2020a,b). Probably a better approach would have been for the academic institutions to face the evidence: formalin and gamma radiation inactivate SARS-CoV-2 virus (Aquila et al., 2020; Pambuccian, 2020), so research and teaching activities including bodies treated by these means should have been allowed to continue, adopting extra safety protocols such as the ones proposed by the respondents (reviewing the medical records, refusing the potentially contaminated cadavers, and testing, freezing and embalming the accepted ones) and further described by Onigbinde et al. (2021) and Lemos et al. (2021).

For the management of non-embalmed material, added preventive measures could be implemented, such as polymerase chain reaction (PCR) tests administered on both the cadaver samples and for the personnel, as well as the compulsory use of disposable personal protective equipment (PPE) and materials, and avoidance of aerosol-generating procedures as defended by Salerno et al. (2020) for autopsies of Covid-19 patients.

The added costs of adopting extraordinary preventive measures, both for research and for teaching activities were the main concern for the participants in the SAE questionnaire. The structural adaptations of the installations (major, 11.1\% and minor, $44.4 \%$ ) that the SAE expert group members considered would be needed, had not been required neither by the institutional $(77.8 \%)$ nor by the regional $(22.2 \%)$ authorities responsible both for the donation programs and for the financing of major structural adaptations. Moreover, the majority of the respondents $(88.9 \%)$ foresaw an increase in the expenses caused by the use of disposable PPEs. Only a $44.4 \%$ expected this increased expenditure to be completely covered by their institutions, while a $55.6 \%$ assumed that the cost would be at least in part attributed to their respective departments. These budget constraints could be the reason for the institution's almost unanimous decision of suspending the dissection room activities, as signaled by Ravi (2020). In a similar 
manner, the higher costs and complexity of the procedures to manage a cadaver infected by Covid-19 would explain both the total closure of the donation services reported by $44.4 \%$ of the participants and the reported $11.1 \%$ of refusal of donations of possible Covid-19 deceased patients. This could cause a decrease in the number of cadavers donated in the future, as signaled by both students (Franchi, 2020) and academia (Evans et al., 2020; Ooi and Ooi, 2020; Ravi, 2020; Singal et al., 2020; Bond and Franchi, 2021), and would require raising public awareness of the continuing need and the value of the donation for the formation of Health professionals (Brasset et al., 2020).

In Spain, the bequeathal programs enforced by SAE members constitute a contractual relation between the donor and the Institution that in the future will receive his/her body. The SAE Expert Group represents the progress toward more ethical practices than the ones prescribed by the regulations promoted by Hutchinson et al. (2019) as a response to the evolution of societal values and needs. However, as reported by the respondents, the pandemic's situation has caused the rejection of body donations under claims of "safety risk" by the institutions. The high cost and complex administrative procedures for funerals are some of the reasons why some people decide to donate their body (Martinez and Brunson, 2019). Given the fact that the Spanish legal system considers the cadaver a "res extra comercio," the body is to be donated both at no cost and without economic compensation for the donor. Consequently, the relatives of a person whose body donation is rejected will have to face un-planned significant costs and complex administrative procedures. If legal responsibilities are accounted for, it has to be remembered that in Spain the responsibility for the donated bodies relies upon the institution that receives it. So, the person ultimately responsible for it is the Head of the Department, the Dean of the Faculty, the Vice-Chancellor or Chancellor of the University, even if the final disposal of the remains is burial or cremation due to safety restrictions (McHanwell et al., 2008). Moreover, difficulties with burials and cremations during the lockdown have increased the pandemic's psychosocial impact (Dubey et al., 2020; Moore et al., 2020).

The possibility of carrying out specific Covid-19 tests, evoked by $55.6 \%$ of the participants, as well as the access to PPEs for both staff and students would cause an increase in the anatomy department's operating costs. More so, given the fact that $77.8 \%$ of the participants reported not to have enough disposable preventive material in stock, due to the donations to the hospitals and critical health services during the height of the pandemics, and the posterior increase in the prizes of those materials. As mentioned, most of the respondents $(55.6 \%)$ considered that the future costs on preventive materials should be covered by the anatomy departments. However, this would result in a clear academic benefit, especially since $55.6 \%$ of the SAE expert group members considered that the perception of their students about the quality of the practical anatomic teaching would increase with the awareness created by the adoption of reinforced safety measures. The training in the renewed safety procedures will reinforce the student's competence on prevention (Ross et al., 2021) as well as strengthen non-traditional discipline-independent skills (NTDIS), adaptability, and resilience (Evans et al., 2018).

Moreover, when, as reported by Bond and Franchi (2021) the teaching of anatomy resumed after the first strict lookout measures were reviewed, it provided, not only anatomical knowledge but also life lessons in ethics and humanity (Jones, 2020), thus addressing the concerns expressed by Pearson
(2020) about the risk of missing the formative values the dissection provides to the future health professionals.

\section{Limitation of the Study}

The present report is limited by the differences in the regulations applied by each Spanish institution, based on the preventive measures applied in each region during the first months of the pandemics. Moreover, the questionnaire has revealed a lack of reliable data about the regulatory procedures and the number of body donations at a regional and national level in Spain. Further research will be required to review and actualize the data about body donations in order to sustain the SAE initiative to regulate and improve the donation protocols and procedures,

\section{CONCLUSIONS}

Despite the perceived risks of the management of cadavers during the pandemics, both the usual embalming procedures and the strict application of all the safety measures for the management of cadavers described in the international and national guidelines, further reviewed during the pandemic outbreak, are adequate to ensure the protection of both students and staff from Covid-19. Dissection is an essential formative activity at all levels of the health sciences education, as well as the foundation of morphological research. Its total abandon is not justified by scientific evidence and represents a break of the donor's confidence placed on the body donation programs.

Extra preventive measures, as the implantation of specific tests for the SARS-CoV-2 virus, the avoidance of aerosolgenerating procedures for non-embalmed cadavers, and the use of disposable protective gear and adequate PPEs could not only increase the security of the staff and students, but also contribute to reinforce their awareness and competences in safety procedures. An evidence-based consensus is required for the adoption of a renewed, comprehensive protocol for present and future donations, as well as for the management, conservation, and procedures to be carried out with the donated bodies.

\section{ACKNOWLEDGMENTS}

For their insightful input in these difficult times, the authors want to thank the following Spanish Anatomical Society (SAE) expert group members: José Aníbal Smith Fernández, Araceli Borbolla Gandara, Alba Coret Franco, Juan de Dios Escolar Castellón, Miguel Ángel Fernández-Villacañas Marín, Jesús García Martín, Sara Hernández Estañol, Lorenzo Mauricio Hernández Fernández, Alino José Martínez Marcos, Blanca Rosa Mompeó Corredera, Matilde Moreno Cascales, Juan Francisco Pastor Vázquez, José Arturo Prada Oliveira, Francisco Ros Bernal, María Santoro, Manuel José Taboada, Francisco José Valderrama Canales, and Jesús Alejandro Villanueva Maldonado.

\section{NOTES ON CONTRIBUTORS}

MARIA-CRISTINA MANZANARES-CÉSPEDES, M.D., Ph.D., is a professor of embryology and human anatomy in the Human Anatomy and Embryology Unit, Department of Experimental Pathology and Therapeutics, School of Medicine and Health Sciences, Faculty of Medicine at the University of Barcelona, Barcelona, Spain. She teaches health science students, mostly dentistry, and her research interest is in 
craniofacial development and bone biology. She served (20152020) as General Secretary for the Association for Dental Education in Europe.

MIKI DALMAU-PASTOR, Ph.D., is an associate professor in the Human Anatomy and Embryology Unit, Department of Experimental Pathology and Therapeutics, School of Medicine and Health Sciences at the University of Barcelona, Barcelona, Spain. He is also a member of the Groupe de Recherche et d'Etude en Chirurgie Mini-Invasive du Pied (Group of Research and Study in Minimally Invasive Surgery of the Foot) in Merignac, France. He teaches health science students, mostly podiatry and his research interest is in clinical and surgical anatomy. He has made significant contributions to the anatomy of the ankle and foot.

CLARA SIMON DE BLAS, Ph.D., is an academic researcher in the Department of Statistics and Operations Research, Computer Science School at Rey Juan Carlos University in Madrid, Spain. She teaches statistics and her research interest is in data envelopment analysis (DEA) and time-series analysis.

MARÍA TERESA VÁZQUEZ-OSORIO, Ph.D., is a full professor in the Department of Anatomy and Embryology, Faculty of Medicine at Complutense University of Madrid, Madrid, Spain. She is Director of the Body Donation and Dissection Room Center, teaches health science students, mostly medicine and her research interest is in surgery and anatomical variations.

\section{LITERATURE CITED}

Ahmed H, Allaf M, Elghazaly H. 2020. COVID-19 and medical education. Lancet Infect Dis 20:777-778.

Aquila I, Sacco MA, Abenavoli L, Malara N, Arena V, Grassi S, Ausania F, Boccuto L, Ricci C, Gratteri S, Oliva A, Ricci P. 2020. Severe Acute Respiratory Syndrome Coronavirus 2 Pandemic: Review of the literature and proposal for safe autopsy practice. Arch Pathol Lab Med 144:1048-1056.

Balta JY, Cronin M, Cryan JF, O'Mahony SM. 2015. Human preservation techniques in anatomy: A 21st century medical education perspective. Clin Anat 28:725-734.

Basso T, Dale H, Langvatn H, Lønne G, Skråmm I, Westberg M, Wik TS, Witsø E. 2020. Virus transmission during orthopedic surgery on patients with COVID-19 - A brief narrative review. Acta Orthop 91:534-537.

Bennett JH, Beeley JA, Anderson P, Belfield L, Brand HS, Didilescu AC, Dymock D, Guven Y, Hector MP, Holbrook P, Jayasinghe JAP, O'Sullivan J, Riggio M, Roger-Leroi V, Scheven B, Sloan AJ, Vandamme K, Manzanares MC. 2020. A core curriculum in the biological and biomedical sciences for dentistry. Eur J Dent Educ 24:433-441.

BOE. 1974. Boletin Oficial del Estado. Decreto 2263/1974, de 20 de julio, por el que se aprueba el Reglamento de Policía Sanitaria Mortuoria. Government of Spain, Ministry of Interior, Madrid, Spain. URL: https://www.boe.es/eli/ es/d/1974/07/20/2263/con [accessed 3 June 2020].

BOE. 2002. Boletin Oficial del Estado. Ley 41/2002, de 14 de noviembre, básica reguladora de la autonomía del paciente y de derechos y obligaciones en materia de información y documentación clínica. Kingdom of Spain, Madrid, Spain. URL: https://www.boe.es/buscar/act.php?id=BOE-A-2002-22188 [accessed 21 December 2020].

Bond G, Franchi T. 2021. Resuming cadaver dissection during a pandemic. Med Educ Online. 26:1842661.

Brassett C, Cosker T, Davies DC, Dockery P, Gillingwater TH, Lee TC, Milz S, Parson SH, Quondamatteo F, Wilkinson T. 2020. COVID-19 and anatomy: Stimulus and initial response. J Anat 237:393-403.

Burgess S, Sievertsen HH. 2020. Schools, skills, and learning: The impact of COVID-19 on education. VoxEU- CEPR's Policy Portal, 01 April 2020. The Centre for Economic Policy Research, London, UK. URL: https://voxeu.org/artic le/impact-COVID-19-education [accessed 11 July 2020].

CDC. 2020. Centers for Disease Control and Prevention. Collection and submission of postmortem specimens from deceased persons with known or suspected COVID-19: Interim guidance. Centers for Disease Control and Prevention, Atlanta, GA. URL: https://www.cdc.gov/coronavirus/2019-ncov/hcp/guidancepostmortem-specimens.html [accessed 3 June 2020].

Cronbach LJ. 1951. Coefficient alpha and the internal structure of tests. Psychometrika 16:297-334.

Desai BK. 2020. Clinical implications of the COVID-19 pandemic on dental education. J Dent Educ 84:512.
DHHA. 2020. Department of Health Hospital Authority. Precautions for Handling and Disposal of Dead Bodies. 10th Ed. Kowloon, Hong Kong: Centre for Health Protection. 24 p. URL: https://www.chp.gov.hk/files/pdf/grp-guide line-hp-ic-precautions_for_handlingi_and_disposal_of_dead_bodies_en.pdf [accessed 10 June 2020].

Dijkhuizen LG, Gelderman HT, Duijst WL. 2020. Review: The safe handling of a corpse (suspected) with COVID-19. J Forensic Leg Med 73:101999.

Dubey S, Biswas P, Ghosh R, Chatterjee S, Dubey MJ, Chatterjee S, Lahiri D, Lavie CJ. 2020. Psychosocial impact of COVID-19. Diabetes Metab Syndr 14:779-788. Eberlová L, Mansfeld L. 2020. New trends in teaching anatomy and our experience with teaching anatomy in Czech during quarantine regarding COVID-19 pandemic. Cas Lek Cesk 159:203-205.

ECDC. 2020. European Centre for Disease Prevention and Control. Considerations Related to the Safe Handling of Bodies of Deceased Persons with Suspected Or Confirmed COVID-19. Technical Report. 1st Ed. Stockholm, Sweden: European Centre for Disease Prevention and Control. 4 p. URL: https:// www.ecdc.europa.eu/sites/default/files/documents/COVID-19-safe-handling-ofbodies-or-persons-dying-from-COVID19.pdf [accessed 3 June 2020].

El-Boghdadly K, Wong DJ, Owen R, Neuman MD, Pocock S, Carlisle JB, Johnstone C, Andruszkiewicz P, Baker PA, Biccard BM, Bryson GL, Chan MT, Cheng MH, Chin KJ, Coburn M, Fagerlund MJ, Myatra SN, Myles PS, O'Sullivan E, Pasin L, Shamim F, van Klei WA, Ahmad I. 2020. Risks to healthcare workers following tracheal intubation of patients with COVID-19: A prospective international multicentre cohort study. Anaesthesia 75:1437-1447.

Evans DJ, Bay BH, Wilson TD, Smith CF, Lachman N, Pawlina W. 2020. Going virtual to support anatomy education: A STOPGAP in the midst of the Covid-19 pandemic. Anat Sci Educ 13:279-283.

Evans DJ, Pawlina W, Lachman N. 2018. Human skills for human[istic] anatomy: An emphasis on nontraditional discipline-independent skills. Anat Sci Educ 11:221-224.

FICEM. 2012. Federative International Committee for Ethics and Medical Humanities of the International Federation of Associations of Anatomists (IFAA). Recommendations of good practice for the donation and study of human bodies and tissues for anatomical examination. Plexus 2012:4-5.

Finegan O, Fonseca S, Guyomarc'h P, Morcillo Mendez MD, Rodriguez Gonzalez J, Tidball Binz M, Winter KA, ICRC Advisory Group on the Management of COVID-19 Related Fatalities. 2020. International Committee of the Red Cross (ICRC): General guidance for the management of the dead related to COVID-19. Forensic Sci Int Synergy 2:129-137.

Franchi T. 2020. The impact of the Covid-19 pandemic on current anatomy education and future careers: A student's perspective. Anat Sci Educ 13:312-315.

George G, Lakhani KR, Puranam P. 2020. What has changed? The impact of Covid pandemic on the technology and innovation management research agenda. J Manag Stud 57:1754-1758.

Government of India. 2020. COVID-19: Guidelines on Dead Body Management. 1st Ed. New Delhi, India: Government of India, Ministry of Health and Family Welfare, Directorate General of Health Services (EMR Division). 7 p. URL: https://www.mohfw.gov.in/1584423700568_COVID19GuidelinesonDeadbo dymanagement.pdf [accessed 10 June 2020].

Gupta N, Pandey S. 2020. Disruption of anatomy dissection practical in COVID-19 pandemic: Challenges, problems and solutions. J Lumbini Med Coll $8: 350$.

Herman JA, Urits I, Kaye AD, Urman RD, Viswanath O. 2021. COVID-19: Anesthesia management recommendations. J Clin Anesth (in press; https://doi. org/10.1016/j.jclinane.2020.109840).

Hirschmann MT, Hart A, Henckel J, Sadoghi P, Seil R, Mouton C. 2020. COVID-19 coronavirus: Recommended personal protective equipment for the orthopaedic and trauma surgeon. Knee Surg Sports Traumatol Arthrosc 28:1690-1698.

Hulin C, Netemeyer R, Cudeck R. 2001. Can a reliability coefficient be too high? J Consum Psychol 10:55-58.

Hutchinson EF, Kramer B, Billings BK, Brits DM, Pather N. 2019. The law, ethics and body donation: A tale of two bequeathal programs. Anat Sci Educ 13:512-519.

Iwanaga J, Loukas M, Dumont AS, Tubbs RS. 2021. A review of anatomy education during and after the COVID-19 pandemic: Revisiting traditional and modern methods to achieve future innovation. Clin Anat 34:108-114.

Iyer P, Aziz K, Ojcius DM. 2020. Impact of COVID-19 on dental education in the United States. J Dent Educ 84:718-722.

Jones DG. 2020. Ethical responses to the Covid-19 pandemic: Implications for the ethos and practice of anatomy as a health science discipline. Anat Sci Educ 13:549-555.

Khoury T, Lavergne P, Chitguppi C, Rabinowitz M, Nyquist G, Rosen M, Evans J. 2020. Aerosolized particle reduction: A novel cadaveric model and a negative airway pressure respirator (NAPR) system to protect health care workers from COVID-19. Otolaryngol Head Neck Surg 163:151-155.

Kramer B, Billings B, Moxham B, Winkelmann A. 2020. IFAA Best Practice Guidelines for Body Donation Programmes During the Novel Coronavirus Pandemic. 1st Ed. Johannesburg, South Africa: International Federation of Associations of Anatomists. 7 p. URL: http://www.ifaa.net/wp-content/uploa ds/2020/05/IFAA-Staement-on-COVID-19_-final-v2.pdf [accessed 18 June 2020]. 
Lemos GA, Araújo DN, de Lima FJ, Bispo RF. 2021. Human anatomy education and management of anatomic specimens during and after COVID-19 pandemic: Ethical, legal and biosafety aspects. Ann Anat 233:151608.

Li Q, Guan X, Wu P, Wang X, Zhou L, Tong Y, Ren R, Leung KS, Lau EH, Wong JY, Xing X, Xiang N, Wu Y, Li C, Chen Q, Li D, Liu T, Zhao J, Liu M, Tu W, Chen C, Jin L, Yang R, Wang Q, Zhou S, Wang R, Liu H, Luo Y, Liu Y, Shao G, Li H, Tao Z, Yang Y, Deng Z, Liu B, Ma Z, Zhang Y, Shi G, Lam TT, Wu JT, Gao GF, Cowling BJ, Yang B, Leung GM, Feng Z. 2020. Early transmission dynamics in Wuhan, China, of novel Coronavirus-infected pneumonia. N Engl J Med 382:1199-1207.

Longhurst GJ, Stone DM, Dulohery K, Scully D, Campbell T, Smith CF. 2020. Strength, weakness, opportunity, threat (SWOT) analysis of the adaptation to anatomical education in the United Kingdom and Republic of Ireland in Response to the Covid-19 pandemic. Anat Sci Educ 13:301-311.

Mahase E. 2020. China coronavirus: WHO declares international emergency as death toll exceeds 200. BMJ 368:m408.

Martinez H, Brunson EK. 2019. Motivations for whole body donation. Pract Anthropol 41:7-11.

McHanwell S, Brenner E, Chirculescu AR, Drukker J, van Mameren H, Mazzott G, Pais D, Paulsen F, Plaisant O, Caillaud MM, Laforet E, Riedere BM, Sanudo JR, Bueno-Lopez JL, Donate-Oliver F, Sprumont P, Teofilovski-Parapid G, Moxham BJ. 2008. The legal and ethical framework governing body donation in Europe - A review of current practice and recommendations for good practice. Eur J Anat 12:1-24.

Mick P, Murphy R. 2020. Aerosol-generating otolaryngology procedures and the need for enhanced PPE during the COVID-19 pandemic: A literature review. J Otolaryngol Head Neck Surg. 49:29.

Moore K, Tulloch O, Ripoll S. 2020. Dying, Bereavement and Mortuary and Funerary Practices in the Context of COVID-19 (April 2020). 1st Ed. Social Science in Humanitarian Action Platform (SSHAP). Brighton, UK: University of Sussex, Institute of Development Studies. 8 p. URL: https://opendocs.ids.ac.uk/ opendocs/bitstream/handle/20.500.12413/15236/SSHAP\%20COVID-19\%20bri ef. $\% 20$ Death $\% 20$ and $\% 20$ funerals.pdf? sequence=1\&isAllowed=y [accessed 10 June 2020]

Moszkowicz D, Duboc H, Dubertret C, Roux D, Bretagnol F. 2020. Daily medical education for confined students during COVID-19 pandemic: A simple videoconference solution. Clin Anat 33:927-928.

Onigbinde OA, Chia T, Oyeniran OI, Ajagbe AO. 2021. The place of cadaveric dissection in post-COVID-19 anatomy education. Morphologie (in press; https:// doi.org/10.1016/j.morpho.2020.12.004).

ONT. 2020. Organización Nacional de Trasplantes. Memoria de la actividad de donación y trasplantes. Government of Spain, Ministry of Health, Madrid, Spain. URL: http://www.ont.es/infesp/Paginas/Memorias.aspx [accessed 3 June 2020].

Ooi SZ, Ooi R. 2020. Impact of SARS-CoV-2 virus pandemic on the future of cadaveric dissection anatomical teaching. Med Educ Online. 25:1823089.

PAHO. 2020. Pan American Health Organization. Understanding Infodemic and Misinformation in the Fight Against COVID-19. Factsheet N.5. 1st Ed. Washington, DC: Pan American Health Organization. 5 p. URL: https://iris.paho. org/bitstream/handle/10665.2/52052/Factsheet-infodemic eng.pdf? sequence $=5$ [accessed 11 June 2020].

Pambuccian SE. 2020. The COVID-19 pandemic: Implications for the cytology laboratory. J Am Soc Cytopathol 9:202-211.

Pather N, Blyth P, Chapman JA, Dayal MR, Flack NAMS, Fogg QA, Green RA, Hulme AK, Johnson IP, Meyer AJ, Morley JE, Shorthland PJ, Strkalj M, Valter K, Webb AL, Woodley SJ, Lazarus MD. 2020. Forced disruption of anatomy education in Australia and New Zealand: An acute response to the Covid-19 pandemic. Anat Sci Educ 13:284-300.

Patil NG, Yan YC. 2003. SARS and its effect on medical education in Hong Kong. Med Educ 37:1127-1128.

Pearson S. 2020. Anatomy: Beyond the COVID-19 pandemic. Acad Med 95:e1. Quinn B, Field J, Gorter R, Akota I, Manzanares MC, Paganelli C, Davies J, Dixon J, Gabor G, Amaral Mendes R, Hahn P, Vital S, O’Brien J, Murphy D, White D, Tubert-Jeannin S. 2020. COVID-19: The immediate response of European academic dental institutions and future implications for dental education. Eur J Dent Educ 24:811-814.

Ravi KS. 2020. Dead body management in times of Covid-19 and its potential impact on the availability of cadavers for medical education in India. Anat Sci Educ 13:316-317.

RCP. 2020. Royal College of Pathologists. RCPath advice on the opening of fresh or unfixed histopathological specimens during infectious disease outbreaks. March 2020. 1st Ed. London, UK: The Royal College of Pathologists. 3 p. URL: https://www.rcpath.org/uploads/assets/4556f1b9-3a6d-4132-b7d0d7c22dfc0a5
c/RCPath-advice-on-the-opening-of-unfixed-histopathological-specimens-durin g-infectious-disease-outbreaks.pdf [accessed 10 June 2020].

Rose S. 2020. Medical student education in the time of COVID-19. JAMA 323:2131-2132.

Ross CF, Pescitelli MJ, Smith HF, Williams JM. 2021. Teaching anatomy with dissection in the time of COVID-19 is essential and possible. Clin Anat (in press; https://doi.org/10.1002/ca.23640).

Salerno M, Sessa F, Piscopo A, Montana A, Torrisi M, Patanè F, Murabito P, Volti GL, Pomara C. 2020. No autopsies on COVID-19 deaths: A missed opportunity and the lockdown of science. J Clin Med 9:1472.

Sañudo JR (Editor). 2015. Acta de Madrid 2015. Facilities and environment of a modern dissecting room. Eur J Anat 19:S1-S52. URL: http://www.eurjanat.com/ data/pdf/eja.15S10001.pdf [accessed 3 June 2020].

Saverino D. 2021. Teaching anatomy at the time of COVID-19. Clin Anat (in press; https://doi.org/10.1002/ca.23616).

SEAP-IAP. 2020. Sociedad Española de Anatomía Patológica. Procedimiento para el manejo de cadáveres de COVID-19. Documento técnico del Ministerio de Sanidad. Versión 02.03.2020. Madrid, Spain: Ministerio de Sanidad. URL: https://www.mscbs.gob.es/profesionales/saludPublica/ccayes/alertasActual/ nCov-China/documentos/Manejo_cadaveres_COVID-19.pdf [accessed 26 May 2020].

Sentell T, Vamos S, Okan O. 2020. Interdisciplinary perspectives on health literacy research around the world: More important than ever in a time of COVID-19. Int J Environ Res Public Health 17:3010.

Sharma D, Rubel KE, Ye MJ, Shipchandler TZ, Wu AW, Higgins TS, Burguin SJ, Ting JY, Illing EA. 2020a. Cadaveric simulation of endoscopic endonasal procedures: Analysis of droplet splatter patterns during the COVID-19 pandemic. Otolaryngol Head Neck Surg 163:145-150.

Sharma D, Rubel KE, Ye MJ, Campiti VJ, Carroll AE, Ting JY, Illing EA, Burgin SJ. 2020b. Cadaveric simulation of otologic procedures: An analysis of droplet splatter patterns during the COVID-19 pandemic. Otolaryngol Head Neck Surg $163: 320-324$.

Sijtsma K. 2009. On the use, the misuse, and the very limited usefulness of Cronbach's alpha. Psychometrika 74:107-120.

Singal A, Bansal A, Chaudhary P. 2020. Cadaverless anatomy: Darkness in the times of pandemic Covid-19. Morphologie 104:147-150.

Srinivasan DK. 2020. Medical students' perceptions and an anatomy teacher's personal experience using an e-learning platform for tutorials during the Covid-19 crisis. Anat Sci Educ. 13:318-319.

UK Law. 2020. Coronavirus Act 2020, Chapter 7. UK Public General Acts. 2020 Ed. London, UK: UK Government. 35 p. URL: http://www.legislation.gov.uk/ ukpga/2020/7/contents/data.pdf [accessed 10 June 2020].

Vázquez-Osorio MT. 2020. Sociedad Anatómica Española, Documento técnico: Manejo de cadáveres COVID 19 (SARS-CoV-2) en los programas de donación de cuerpos para docencia e investigación. 1st Ed. Madrid, Spain: Universidad Complutense de Madrid. 14 p. URL: http://www.sociedadanatomica.es/documentos/ DOCUMENTO-TECNICO-SAE-COMPLETO.pdf [accessed 10 September 2020]. WHO. 2020. World Health Organization. Prevención y Control de Infecciones para la Gestión Segura de Cadáveres en el Contexto de la COVID-19, Orientaciones Provisionales, 24 de Marzo de 2020. 1st Ed. Geneva, Switzerland: World Health Organization. 6 p. URL: https://apps.who.int/iris/bitstream/ handle/10665/331671/WHO-COVID-19-IPC_DBMgmt-2020.1-spa.pdf?seque nce $=1$ \&isAllowed $=y$ [accessed 3 June 2020].

Workman AD, Jafari A, Welling DB, Varvares MA, Gray ST, Holbrook EH, Scangas GA, Xiao R, Carter BS, Curry WT, Bleier BS. 2020. Airborne aerosol generation during endonasal procedures in the era of COVID-19: Risks and recommendations. Otolaryngol Head Neck Surg 163:465-470.

Wu V, Noel CW, Forner D, Zhang ZJ, Higgins KM, Enepekides DJ, Lee JM, Witterick IJ, Kim JJ, Waldron JN, Irish JC, Hua QQ, Eskander A. 2020. Considerations for head and neck oncology practices during the coronavirus disease 2019 (COVID-19) pandemic: Wuhan and Toronto experience. Head Neck 42:1202-1208.

Yaacoub S, Schünemann HJ, Khabsa J, El-Harakeh A, Khamis AM, Chamseddine F, El Khoury R, Saad Z, Hneiny L, Cuello Garcia C, Muti-Schünemann GEU, Bognanni A, Chen C, Chen G, Zhang Y, Zhao H, Abi Hanna P, Loeb M, Piggott T, Reinap M, Rizk N, Stalteri R, Duda S, Solo K, Chu DK, Akl EA. 2020. Safe management of bodies of deceased persons with suspected or confirmed COVID-19: A rapid systematic review. BMJ Global Health 5:e002650.

Zarocostas J. 2020. How to fight an infodemic. Lancet 395:676.

Zingaretti N, Contessi Negrini F, Tel A, Tresoldi MM, Bresadola V, Parodi PC. 2020. The impact of COVID-19 on plastic surgery residency training. Aesthetic Plast Surg 44:1381-1385. 